\title{
Blogging Everyday Life in Chinese Internet Culture
}

\author{
HAIQING YU* \\ The University of Melbourne
}

Since the mid-1990s China has undergone an explosive growth in Internet usage and coverage. China became the second largest Internet nation (next to the United States) in 2002, with 59.1 million Internet users. By June 2006, the number hit 123 million (although this still comprises only 9.4 per cent of China's total population of 1.3 billion). ${ }^{1}$ The Internet has become an integral part of the daily lives of urban Chinese. For most Chinese Internet users, the Internet provides aggregated sources of a rich variety of content: a platform for online commerce, a huge virtual billboard for advertisements, games and social networking (including cyberlove, or wang lian).

This entertainment-and-consumption pattern of Internet use at the micro, individual level is often put side by side with a control model at the macro, institutional level, which views information and communication technologies (ICT) as a means of control (see, for example, Qiu, 2007). People in the West are frequently told about the suppression of freedom of speech by the Chinese government, constraints on politically sensitive websites, arrests of cyber activists, and global Internet search companies (such as Google, Yahoo and MSN) giving in to the Chinese government by imposing stricter censorship to control the flow of Internet information. Both the micro and macro perspectives on Chinese ICT are at the same time counterbalanced by a meso-level view that takes the Internet as a tool for political activism and a platform for democratisation (see, for example, Schroeder, 2005). The use of the Internet as a tool for political activism has characterised overseas Chinese political movements, such as the Uyghur opposition movement (representing cyber-separatism) (see Gladney, 2004) and the Falun Gong protest movement (representing cyber-sectarianism) (Thornton, 2002). The macro and meso perspectives are usually intertwined with each other, as the use of the Internet by dissidents and control of the Internet by the Chinese government are regarded as two sides of the same coin (Chase and Mulvenon, 2002).

The apparent dichotomy of control versus freedom has constituted the internal logic of China's ICT development and dominated Western scholarship on Chinese new media.

*Correspondence Address: School of Culuure and Communication. The University of Melbourne, Parkville, 3030, Victoria, Australia. Emiil: hyu@unimelb.cdu.au

ISSN 1035-7823 print/ISSN 1467-8403 online/07/(040423-11 $6,20(17$ Asian Studies Association of Australia DOI: $10.1080 / 10357820701710724$ 


\section{Haiqing $Y u$}

Recently, however, a socio-political economy model has been developed that tries to embed China's state-led and market-driven "digital revolution" or "great digital leap forward" 2 within the broader developmental path of China"s post-socialist era. From this perspective, China's ICT development is not only significant within the context of globalisation, but also critical to the social and cultural domains of Chinese modernity. Yuezhi Zhao (2007), for example, examines the aggressive top-down "digital revolution" side by side with the enormous social and cultural tensions represented by industrial workers, farmers, and Falun Gong members - all subaltern subjects in relation to the elite nature of Chinese ICT promoter's and users. For Zhao, these subaltern subjects have been "at the forefront of contesting the terms of China's 'digital revolution"", and they represent the "unevenness and incommensurability of the digital age" (Zhao, 2007, p. 113).

Zhao's article underscores the interface between the economic, political, and socio-cultural dimensions of ICT in China. She emphasises the interaction of the meso and macro levels of ICT in China - that is, the interaction of the state-led and market-oriented ICT developmental strategy and the multiple forms of social contestation that such a strategy creates. In this integrated study of Chinese ICT, the "everyday" is ubiquitous. The central role of the everyday dimension in the interplay between the micro, meso and macro levels in Chinese Internet culture, however, has not yet been fully investigated. Chinese Internet development in recent years, particularly the fast growth of blogging since 2002, has posed new questions about digital media practices by new consumer-cum-producers (or "prosumers") and their embedding in contemporary Chinese culture. While giving us glimpses of contemporary Chinese Internet culture, their blogging practices also invite an investigation into the cultural politics of the everyday in China.

I have demonstrated elsewhere that, despite the increasingly sophisticated effort by the Chinese government to control the Internet, the new media can become a new venue for individuals to exercise citizenship, not through overt resistance, but through a process of re-subjectification via mediated expression, social interaction, and circulation of their own media stories ( $\mathrm{Yu}, 2006 ; 2007)$. As cultural producers (as well as consumers), these new media users use mobile texting and online posting to form a culture of circulation in the act of consumption. The seemingly apolitical media practices of the consumer masses turned out to be political in the end as they influenced the way people think about politics, culture and society. This article continues my previous studies on the popular and everyday dimension of new media usage in China. It focuses on a relatively new phenomenon in Chinese Internet culture - blogging.

The year 2005 is regarded as the year of Chinese blogging. First, two of the largest Chinese-language commercial Internet service providers (ISPs), called sina.com and sohu.com, together with bokee.com (one of the major players in Chinese blogosphere a collective term of all blogs) sponsored competitions to stimulate blogging among Chinese Internet users. Next, a series of "blogger events" took place that further justified the celebration of the coming of age of Chinese bloggers. This included production of a bloggers' online movie 'A Hard Day's Night' ${ }^{3}$ and an online video called 'A Bloody Case Caused by a Steamed Bun [mantou]', which set out to spoof the 2005 blockbuster, The Promise, by famed film producer Chen Kaige. ${ }^{4}$ These events provide a rich context in which to explore the phenomenon of blogging in everyday Chinese Internet culture. In this study I will focus on these cases in order to assess the new development of digital media practices in the context of everyday politics in China. 


\section{Blogging in China}

Blogging is a creative textual-visual-audio posting and viewing practice. Blogs often combine text, images and links to other blogs, webpages, and other media related to their topics; they can be textual, visual (photoblog, vlog), or audio (podcasting). Blogs often provide commentary or news on a particular subject, such as food, politics or local news. Some function as personal online diaries; others function as social forums and part of a wider network of social media. In other words, blogging represents a new way of living.

Blogging started in China in 2002 with the initial operation of blogchina.com in August. It quickly took off in 2003 when Mu Zimei started her web diary at blogen.com to record and publicise her very active sex life with different men. ${ }^{5}$ Blogging became the hottest keyword in Chinese search engines with the popularisation of Mu Zimei and her blog. In May 2004, the first conference on online communication (with particular focus on blogging) in China was held in Nanjing. By the end of 2005, blogging was no longer simply an online practice for a small group of elite lnternet users; it had been popularised and become a way of living for urban Chinese. ${ }^{6}$

By the end of 2005 the number of Chinese bloggers had reached 16 million, while the total number of Internet users had reached 111 million (Zhang, 2006). ${ }^{7}$ According to a survey on blogging in China, by June 2006 the number of Chinese bloggers had reached 17.485 million, or 14.2 per cent of China's total 123 million Internet users, and the number of Chinese blog readers had reached 75.565 million, or 61.4 per cent of the total Internet population in China (CNNIC, 2006).

The year 2005 has been claimed as a milestone year in the short history of blogging in China, not only because of its rapid growth in terms of number and popularisation among Chinese lnternet users, but also because of its impact on everyday life. In blogging, commodity culture (manifested as consumption) and knowledge culture (manifested as media production) have combined to form a new Internet culture, which in turn reflects the general trend of cultural transformation in China today.

The first case to be examined here is the group bloggers' movie 'A Hard Day's Night'. 'A Hard Day's Night' is a 50-minute long digital video, made by a group of bloggers in Beijing who got together offline and decided to make a movie to enjoy themselves and poke fun at each other and their lives. They claim to have zero specialty and professionalism (in filmmaking), zero sincerity, zero special effects, zero logic, and zero box sales. The movie tells of the misfortune suffered by a man named Xiao Qing who works for a blogging website. He is detained by the police on his way home one night for his resemblance to a legendary Hong Kong actor-turned-bank robber. What distinguishes the movie is not jts thematic matter (it does not have any theme) or its editorial technique (it is shot with only one home digital camera and edited on an old computer), but the way in which these blogger-actor-producers produce and promote their product and the spirit of playfulness embodied in the movie.

Claimed as embodying "entertainment for entertainment's sake" (rather than the official ideology of "education through entertainment" in media production), "A Hard Day's Night' is a mischievous prank by a group of bloggers. ${ }^{8}$ As an offshoot of blogging, the movie was promoted offline by these first-time "movie-makers" through a mock-Oscar ceremony on 5 January 2006 , which was attended by all movie-making participants (who were all prize-winners) and their friends and associates in Beijing's media circle. It was 
again publicised online through blogging when the blogger-playwright-actordirector-producers returned to their individual blogs to write about their experience in making the movie, employing the same kind of playful, hippy spirit that characterises conversations throughout their movie. This spirit can be traced back, most recently, to popular satirist Wang Shuo, whose rebellious spirit and satirical writing have earned him the title "hooligan [lizmang] writer" (Barmé, 1992). The playful spirit has been used as a trademark in the marketing and publicity endeavours of the moviemaker-bloggers. As one of them writes, "In the age when people live a boring and unexciting life, we did something entertaining with a playful spirit" (Lao Liu, 2006). In doing so, these bloggers deny any political purpose or even innuendo in making the movie, although references to contemporary Chinese politics infuse the whole movie. Their playful spirit quickly spread in the Chinese Internet, among their blog readers, their fans, and fans' fans. 'A Hard Day's Night' became an online spectacle at the end of 2005 and in early 2006.

At almost the same time, a spoof of the feature movie The Promise (2006) by famed film producer Chen Kaige caused a sensation in the Chinese Internet. This spoof, entitled 'A Bloody Case Caused by a Steamed Bun' (hereafter 'Steamed Bun') was made by Hu $\mathrm{Ge}$, a blogger and amateur digital video producer based in Shanghai, to mock Chen Kaige's blockbuster. Like 'A Hard Day's Night', it was made in December 2005 and was widely circulated online in January 2006 , just weeks after the official release of Chen's film in China.

The 20-minute long DV borrows video footage from The Promise but infuses it into the format of 'China Legal Report', a legal education program by China Central Television (CCTV). It tells a story about the police investigating a murder case, using the format, style and language of the CCTV legal program. Even the insertion of advertisements in the program copies that of 'China Legal Report'. It starts with the typical opening style of the official legal program:

One little steamed bun caused an astonishing murder case. The nature of innocent kids was twisted by a little incident (over fighting for a steamed bun)... The police were ordered to find and arrest the murder suspect... The case proved to be very intriguing and complicated. Welcome to the end of year 2005 special issue of 'China Legal Report' - 'A Bloody Case Caused by a Steamed Bun' (video excerpt, 'Steamed Bun').

The tone of the narrator is serious (as is that of the official CCTV version); the plot and message the DV carries, however, are characterised by mockery, paradox, sarcasm and deliberate misuse and misinterpretation of mainstream ideology. 'Steamed Bun' mocks the "sublime" and "grand" (represented by The Promise) and the "official" and "serious" (CCTV's 'China Legal Report') through its "seriously comical" narration of a mundane case caused by a triangular love affair. The power of the spoof is further enhanced by Hu's skilful manoeuvring of various forms of music in editing the DV, ranging through Western (rap), folk ('Love Song from Tea Mounlain'), popular ('Cinderella') and mainstream ('Entering the New Era').

Unlike the case of 'A Hard Day's Night', Hu Ge never intended to publicise his DV, and was even surprised when the DV became a popular hit just a couple of days after it was posted online by his friends. 'Steamed Bun' quickly generated a fan community. These fans of 'Steamed Bun', also known as "mantou fan" or steamed buns, posted articles, 
made posters, and blogged 'Steamed Bun' in their websites, forums and blogs to spread the spoof, and support Hu Ge in his artistic experiment, especially when Chen Kaige threatened to sue Hu over intellectual property issues. ${ }^{9}$ Hu had not intended to create a stir but he reluctantly became an "anti-fan" artist. In this way he was seen to represent the larger body of amateur online film and video production that had arisen in China with the emergence of easily accessible digital video techmology and blogging. He is "antifan" because he is not a DV artist seeking to promote fandom of the film. Hu produced a whole new storyline by patching together the original footage in the film with totally different and anti-climactic dialogues and narration. The effect was to mock and deconstruct the original film and its thematic matter. He is also "anti-fan" because he was never interested in joining or forming any fandom community. It is the Internet and particularly blogging that gave his spoof its rapid and widespread circulation and a surprising degree of public visibility. As "Steamed Buns" became a synonym for " $e$ ' $g a o^{\circ}$ " or spoof, $\mathrm{Hu}$ became an Internet celebrity, representing the spirit of the grassroots [cao gen] majority.

The "grassroots spirit" is the spirit of the masses as consumers and amateur producers of media products. It represents the essence of everyday life and the energy of blogging culture. In both cases, blogging has become an essential part of everyday life for those who blog, as blog writers and readers. No matter how these bloggers use blogs, blogging - an online practice of knowledge culture - has altered the way in which consumer culture operates. The following passage is borrowed from Henry Jenkins (2002) as a snapshot of my following discussion on blogging and its relation to everyday cultural consumption and production:

In an era marked both by the expanded corporate reach of the commodity culture and the emerging importance of grassroots knowledge culture, consumer power may now be best exercised by blogging rather than jamming media signals (Jenkins, 2002, p. 168).

\section{Blogging Everyday Life}

Many theorists, from Henri Lefebvre and Pierre Bourdieu to Michel de Certeau, have theorised everyday life and consumption. Everyday life has started to occupy a central position in the study of media and media technologies (e.g. Silverstone and Hirsch, 1994; Mackey, 1997). These earlier studies have succeeded in turning "away from the habit of thinking in terms of what the media do to people", to use James Halloran's often quoted remark, towards the idea of "what people do with the media" (qtd. in Morley, 1992, p. 51). Consumption is no longer considered a domain of "passivity" but has become central to the cultural production of a symbolic order of everyday life and politics. This is a salient feature of postmodernity. In postmodernity, consumption has become part of self-construction and a process of popular resistance. As Fuat Firat and Nikhilesh Dholakia (1998) aptly summarise,

In modernity, the subject (the consumer being) encounters the objects (products) as distinct and distances from her/himself. In postmodern consumption, the consumer renders products part of her/himself, becoming part of the experience of being with products (Firat and Dholakia, 1998, pp. 96-97). 
This postmodern view of consumption has also characterised studies of consumption in Asia such as Chua (2000). These studies have demonstrated how the social, political, economic and cultural dimensions of consumption underpin the identity politics of the emergent middle class. In the Chinese case, digital gadgets such as mobile phones were associated with the power and identity of the new rich in the early 1990s (Goodman, 1996). By the time blogging took off in China in 2003, however, around 250 million Chinese, or one out of every five people, owned a mobile phone (People's Daily, 2003). Digital devices such as mobile phones and the Internet are no longer mere symbols of the latest fashion but everyday channels of communication, entertainment and networking. Consumption, especially consumption of new media, has become part of the experience of being reassuringly modern for urban Chinese.

In the era before the new media became an everyday reality for urban Chinese, people were mainly regarded as consumers who might actively decode media messages but were not equipped to narrate their own stories and make their voices heard and "enlarged" through circulation. In the era of new media and communication, however, new forms of "publicness" are created based on non-localised, non-corporal, non-dialogic, and non-reciprocal forms of communication across national and cultural boundaries. Mobility and mobilisation are privatised via mediated quasi-interactions among different forms of "publicness" (Thompson, 1995). Communication becomes versatile, immediate, and more democratising in that ordinary people can log onto a BBS to read or post social commentary, use their mobile phones to talk and send a synopsis of issues of common concern, or blog and reblog texts, images and sounds, not just across China but in global cyberspace, almost any time and anywhere. These bloggers (and new media users in extension) are not merely spectators or consumers. They are active participants in the production of symbolic values by being part of a culture of circulation. Blogs, home-made videos, and spoofs of blockbusters are both banal and ubiquitous, and represent a postmodern pattern of consumption-cum-production. Blogging empowers people to take coordinated actions based on mutual trust and support, as my two case studies (and numerous other cases) have suggested. The producers of ' $\mathrm{A}$ Hard Day's Night' deliberately used blogging to spread their message of fun and playfulness. The bloggers who formed the community of "mantou fan" to support $\mathrm{Hu} \mathrm{Ge}$ and his 'Steamed Bun' spoof were well aware of their influence. The coordinated actions by the bloggers to network and circulate their work may not be considered political, or even confrontational, but rather efforts by amateur media producers to play with words and audio-video resources to offer alternative messages to the Chinese public.

As a form of knowledge production and circulation, blogging also represents a rebellious force in the new media culture, which is an essential part of the emergent knowledge culture. It derives from the old commodity culture, but deconstructs it from inside. As Pierre Levy (1997) points out, the emergent knowledge culture is gradually altering the ways in which the commodity culture operates. Although knowledge culture cannor operate outside the commodity culture, the former, which emerged from popular new media use, serves as the "invisible and intangible engine" to propel the dismantlement of the order of the old commodity culture (Levy, 1997, p. 237). This observation is supported by Mark Poster (2004) when he points out:

Here the older legal and economic structures that insure commodification on the basis of authorship are disintegrating before our eyes. Copyright law, designed for an age when cultural objects were material commodities like cars and cereals, 
is now an obstacle to the development of a post postmodern culture, one no longer characterized by fixed cultural objects and positions of creator and consumer, but by fluid text, sounds and images, costless reproduction and distribution, and potentially collective creation (Poster, 2004, p. 421)

The culture industry can resist consumer creativity. In the case of 'Steamed Bun', Chen Kaige threatened to sue $\mathrm{Hu} \mathrm{Ge}$, who, fearing for his financial future, apologised to Chen for his spoof of The Promise. Hu's "mantou" fans, however, continued their support of him and urged him to further his digital experimentation by feeding him ideas for other spoofs. One can see from this that the knowledge culture (to continue using Levy's term) encourages its participants to join in the reading-writing, consumption-circulationproduction continuum. The Internet has played a central role in empowering ordinary people to narrate and circulate their own media products. In this way ordinary people are able to constitute themselves as active agents in narrating their own stories.

The emergence of the postmodern consumer and the integration of consumption and production in the cultural domain have characterised discussions on consumption and everyday life in the era of digital media and communication technologies. I have used two cases to demonstrate the effect of Internet use in China (especially through blogging) and its contribution to the new media culture and emergent knowledge culture in the Chinese context. I have viewed blogging as representing the postmodern pattern of media consumption and production on the one hand, and a rebellious force against the mainstream culture on the other hand. As a rebellious force, blogging does not, however, challenge the mainstream culture (be it political or business), but rather deconstructs it through playful (mis)use (and often juxtaposition) of the available resources. "Entertainment for entertainment's sake" has become the trademark of Chinese blogging and serves as a collective manifesto in the Chinese blogosphere. Embodied in their spirit of playfulness is the refusal of seriousness. This spirit is in itself a tactical form of resistance.

\section{The "Graying" of Chinese Internet Culture}

The tactical form of resistance represented by blogging is not a new phenomenon in Chinese culture. There has been a long string of cultural events in contemporary China that fall into the category of popular resistance. From Cui Jian's rock-n-roll and Wang Shuo's "hooligan" novels (as mentioned earlier), to the cultural T-shirt craze that swept China's capital in the early 1990s (Barmé, 1999), a tactical use of language has characterised the various forms of popular resistance in contemporary China. As Geremie Barmé observed in the late 1990s,

Since language, or public parole, and reality had for many decades enjoyed at best only an accidental relationship in China, there was no great difficulty for a creative artist to engage in an ironic inversion of language (Barmé, 1999, p. 174).

He went on to point out that both Wang Shuo's writings and the cultural T-shirts had the effect of "highlighting the absurdities of both language and the reality it supposedly represented, playfully working with signs - literally Chinese characters - and meaning as part of an attempt to reveal what was hidden or perhaps felt behind the facade of words" (Barmé, 1999, p. 174). 


\section{Haiging $Y u$}

The playful use of words and contemporary Chinese political culture, in the way of "soft-core deconstruction" (to use Barmé's words in describing cultural T-shirts), has been a consistent feature in popular resistance, although people who participate in such a creative business seldom admit the subversive nature of their work. As alrealdy pointed out, 'A Hard Day's Night' is infused with this same play with words and with mainstream culture. In the beginning of the film, for example, when Xiao Qiang (the lead actor) is stopped by the police, the viewer's attention is immediately engaged by this contemporary version of a Maoist greeting that characterised the height of the Cultural Revolution:

(Policeman) Adhere to "Three Represents" - please show your ID card;

(Xiao Qiang) Adhere to "Three Closenesses" - please wait a second.

"Three Represents" represents the ideology of the Jiang Zemin regime, while "Three Closenesses" represents that of the Hu Jintao regime, especially in "thought work" that is, ideology and political work. ${ }^{10}$ In the short exchange between the policeman and Xiao Qiang, political correctness is fleshed out. This comical deployment of political correctness continues as Xiao Qiang, now handcuffed and forcibly taken away, deplores his tragic fate as an innocent citizen of China:

I support the unification of Taiwan; I voted for Li Yuchun in the Super Girl contest. You've made a mistake; it's a mistake! It is not me who went to massage parlours for prostitution; it is not me who caused the explosion of the chemical factory due to his negligence of duty; it is not me who stopped Faye Wang from singing; it is the chickens, not me, who spread the bird flu.

This is a farrago of Chinese "political correctness". It refers to mainstream CCP views on the Taiwan issue, to issues in popular culture, such as "Super Girl", who is a Chinese version of "American Idol", and the pop star, Faye Wang, who retreated temporarily from show business due to pregnancy, and to hot social issues such as the anti-corruption campaign and the social disruption caused by bird flu. The same deployment of political correctness and comical use of language also characterises 'Steamed Bun', though in a different way. While 'A Hard Day's Night' features deliberale juxtaposition of contrasts, nonsensical parodies, and sudden twists in the spoken dialogue, 'Steamed Bun' features the technique of spoof through a carefully devised plot and a hybrid format rather than through inventive language.

In both cases, parodies of mainstream ideology, mockeries of blockbusters, and caricature of hot social issues and persons have characterised the production of spoofs through blogging. The spoof is similar to the Cantonese technique of wu li tou, made popular in mainland China through such Hong Kong films as Stephen Chow's 1990 hit All for the Wimner. The blogged spoof aims to deconstruct anything serious, grand, sublime and mainstream. It produces a comic effect through mockery, sarcasm, paradox, irony and subtle subversion. In this way the word e'gao [spoof] has become increasingly popular with the spread of blogging in China, and is used to refer to the popularisation of digital technologies among ordinary Internet users.

These creative "artists", whether they are professional art producers or ordinary users of the new media, are not necessarily trying to engage in confrontation with the state. After 
all, they benefit from the opening of Chinese society, the gradual retreat of the state from the everyday domain of people's lives, and the techno-economic growth under the authoritarian leaders of the post-1978 reform movement, Deng Xiaoping, Jiang Zemin and Hu Jintao. Many of them are state employees, such as the bloggers in 'A Hard Day's Night', who know the political boundaries of word games in China. Bloggers who produce and circulate their spoof articles and audio-video products online do not consider themselves, and are not considered by state authorities, to be opponents of the system. When Reuters termed 'A Hard Day's Night' a political satire about contemporary Chinese politics, it annoyed the movie's blogger-producers. One of them wrote in his blog: "Il is inevitable that those foreigners link our entertainment-oriented blogger movie with political life - nowadays politics has assumed command for foreigners rather than us [Chinese]" (Anonymous, 2006). "

Different interpretations of Chinese blogger events only highlight different perspectives and positions of the interpreters in question. While overseas observers are quick to read political messages into the Chinese blogging practices, Chinese practitioners themselves are generally reluctant to relate their playful use of language and events to the reality they supposedly represent. What these bloggers enjoy is not a momentary stardom or "martyrdom" through creation of the spoof, but the promise of moments of tactical and light-hearted resistance through playful collective action. This light-hearted resistance, which forms the core element of Chinese popular culture, has migrated to the online world with or without state approval.

The rapid growth of blogging and its growing influence on the public has not led to repression by the state except in cases where political boundaries are blatantly crossed. Nor have bloggers stopped producing spoof products online, in spite of continual commentaries from overseas observers about their possible political implications. It is not just evocative words but visual and auditory pleasure that explains the popularity and continued growth of these amateur spoofs. In the early 1990s leaders of the cultural T-shirt craze (when young people wore T-shirts with ambiguous messages) would say "Life is a bore", whereas today's bloggers proclaim that "Life is a play". About a decade after the Internet took off in China, "the graying of Chinese culture" has advanced to the digital world. In other words, Chinese Internet culture is becoming gray.

"Gray", according to Barmé (1999, p. 100), is a syndrome that:

combined hopelessness, uncertainty, and ennui with irony, sarcasm, and a large dose of fatalism. It was a mood that enveloped both the individual and an ambience that suffused the urban world. It was a zeitgeist that was noticeably prevalent in youth culture (Barmé, 1999, p. 100).

The cultural T-shirt craze was a product of the "gray sentiment" of Chinese culture in the 1990s. In the twenty-first century it is blogging that represents the "graying" of Chinese Internet culture. Embodied in the playful spirit of these bloggers, however, is not so much hopelessness as confidence in their role as media consumer-cum-producers who have the technical and cultural capacity to entertain themselves and the mation, both Chinese and non-Chinese.

Geremie Barmé used a statement from a Chinese official report on the cultural T-shint craze to summarise his survey on the "glaying of Chinese culture" in the 1990s: 


\section{Haiging $Y_{u}$}

The "gray culture shirts" have come and gone. Although this phenomenon has disappeared, it does not mean that the "gray sentiments" harboured by certain individuals have vanished. Who knows, next year they may discover some new medium for expression (quoted in Barmé, 1999, p. 142).

As this article has demonstrated, "gray sentiments" have migrated from the urban youth in the capital city and China's metropolises to a wider community in the online world. In this way the Internet has become the new medium for expression of "gray sentiments". The colour "gray" has characterised Chinese popular culture in the post-Mao era. The "graying" of Chinese culture will continue to inform everyday life in the era of new media and communication technologies, in the form of mobile texting, online posting, blogging, and any new means or medium that comes along.

\section{Notes}

1. Internet User Growth in China (June 2001-June 2006) available at http://www.cnnic.com.cn/index/ $0 \mathrm{E} / 00 / 11 /$ index.Ittm.

2. A pun on the infamous "Great Leap Forward" from 1958 to 1962 under Mao's lcadership.

3. 'A Hard Day's Night', available at htp://w'ww.koook.com/special/xiaoqiang/.

4. 'A Bloody Case Caused by a Steamed Bun', available at http://news.sohu.com/s2006/06mantou/. Although the two blogger events started to enjoy great popularity and publicity in the first days of January 2006, they were produced in 2005 and derived from the socio-cultural context of 2005 . It is therefore justifiable to view them as outreach of 2005 blogger events.

5. Now Mu Zimei hats shifted to podcasting. Although quite notorious and controversial she still enjoys media attention and her podcasting attracts around 10,000 visits a day. Mu Zimei has opened several blogs at different websites. Her blog at blogen.com is muzimei.blogen.com/index.shml.

6. A research article by Chinalabs.com (established by Fang Xingdong and Wang Junxiu. founders of blogchina.com, in 1999) defines four stages in the growth of blogging in the global blogosphere: the incubation stage, the initial growth stage (led by the intellectual elite), the popularisation stage, and the mature stage (http://news.xinhuanet.com/newmedia/2006-(02/14/content_4174072.htm). Although blogging has become a popular cultural phenomenon in China, I think it is still in its popularising and developmental stage, especially considering the number of bloggers (compared with the number of Chinese Internet users and China's total population) and their concentration in urban and coastal areas.

7. See 'Growth of Chinese Bloggers 2003-2007'. Available al hup://news.xinhuanct.com/newmedia/ 2006-02/14/content_4174072.htm.

8. Interestingly, these bloggers all work in the media industry as journalists, editors, photographers or freelance writers. They blog online and form an informal blogger salon oflline. As bloggers, they use a different writing style and language from those they employ in writing for their bosses. The topic of blogging and its impact on traditional media and journalism in the Clinese context deserves further study. It is nol the central task of this article. however, to address the issue in detail.

9. For example, onc "mammo" fan wrote: "If Chen Kaige finds trouble with you, notify us immedialely at tianya.com; if Chen Kaige throws a tantrum al you, we'll all be there to protect you" (htip://yulc.solut. $\mathrm{com} / 2006(1213 / \mathrm{n} 227754906$.shuml).

10. Jiang Zeming's "Three Represents" philosophy is a redefinition of the Chinese Communist Party (CCP) away from its original roots as the avant-garde party of the proletariat. Jiang's new philosophy gocs as follows: the CCP represents the demands of advanced productive forces; the $\mathrm{CCP}$ represents the promotion of advanced culture: the CCP represents the basic interests of the broad masses of the people. Jiang's successor Hu Jintao has taken on the "lorch" of the "Three Represents" and added a "human face" 10 it. Hu's "Three Closenesses" refer to "close to reality, close to the masses, and close to bife".

11. This is a pun on the common Matoist expression "politics is in command", 


\section{References}

Anonymous (2006) Xiao Qing lixian ji - zhongguo boke dianying chulu, 10 January 2006. Available at www.chndv.cn/hy/nzp/2006-01-10/1031.huml, accessed 19 October 2006.

Barmé, Geremic R. (1999) In the red (New York; Columbia University Press).

- (1992) Wang Shuo and liumang ("hooligan') culture. The Australian Joumal of Chinese Affairs 28 (July), pp. 23-64.

Chase, Michacl and James Mulvenon (2002) You ve got dissem: Chinese dissidem use of the internet and Beijing 's commer-strategies (Santa Monica, CA: RAND, National Security Research Division Center for Asia Pacific Policy)

CNNIC (China lnternet Network Information Center) (2006) Zhongguo boke diaocha baogao, September 2006. Available at http://www.cnnic.com.cn/uploadfiles/pdf/2006/9/28/182836.pdf, accessed 19 October 2006.

Firat A. Fuat and Nikhilesh Dholakia, eds (1998) Consuming people: From political exonomy to theaters of consumption (London and New York: Routledge)

Gladney, Dru C. (2004) Dislocaing Chima: Reflections on Muslims, minorities, and other subaltem subjects (London: Hurst \& Company).

Jenkins, Henry (2002) Interactive audiences?, in Dan Harries (ed) The new media book (London: British Film Institute).

Levy, Pierre (1997) Collective intelligence: Mankind's emerging world in cyberspace (Cambridge: Perseus).

Lao Liu (2006) Dongtian de shigou, 6 January 2006. Available at http://bbs.koook.com/bbs/viewtopic php? $1=9952$, accessed 19 October 2006.

Mackey, Hugh (1997) Consumption and everyday life: Culture, media and identities (London: Open University Press/Sage).

Morley, David (1992) Television, audiences, and cultural studies (London and New York: Routledge).

Poster, Mark (2004) Consumption and digital commodities in the everyday. Culural Studies 18(2/3), March/ May, pp. 409-23.

Qiu, Jack Linchuan (2007) The wireless leash: Mobile messaging service as a means of control, Imernational Journal of Communication 1, pp. 74-91.

Schroeder, Sharon (2005) The intemet as a tool for political activism in China, online anicle. Available a http://globalmon.civiblog.org/_attaclments/1774557/Chinainternetloolforpoliticalactivism2.pdf, accessed 20 October 2006

Silverstone, Roger and Eric Hirsch (1994) Consuming technologies - Media and information in domestic spaces (London and New York: Routledge).

Thompson, John B. (1995) The media and modemity: A social theory of the media (Cambridge: Polity Press).

Thornton, Patricia (2004) The new cybersects: Resistance and repression in the reform era, in Elizabeth J. Perry and Mark Selden (eds) Chinese society: Change, conflict and resistance. $2^{\text {nd }}$ edition, pp. 247-70 (London and New York: Routledge).

Yu, Haiging (2007) Talking, linking, clicking: The politics of AJDS and SARS in urban China. posinions: Eas Asia Cultures Critique 15(1), pp. 35-64.

(2006) Fron active audience to media citizenship: The case of post-Mao China. Social Semiorics $16(2)$ pp. 303-26.

Zhao, Yuezhi (2007) After mobile phones, what? Re-embedding the social in China's "digital revolution". International Joumal of Communication 1. pp. 92-120.

Zhang Xuguang (2006) Zhongguo ren shangwang huadia qian yi 2005 nian zhongguo wangmin da 1.11 yi, online article, 18 January 2006. Available at hutp:/tech.sina.com.cn/i/2006-01-18/065782.3022.shuml, accessed 19 October 2006. 